\title{
Spatial and temporal distribution of Pseudis minuta (Anura, Hylidae, Hylinae) and environmental variables related to its reproductive activity in Reserva Biológica do Lami, southern Brazil
}

\author{
Caroline Zank ${ }^{1}$, Marcos Di-Bernardo 2 , Raúl Maneyro ${ }^{3}$, Patrick Colombo ${ }^{4}$, \\ Luciana A. Fusinatto ${ }^{5}$ \& Luis Fernando M. da Fonte ${ }^{1}$
}

1. Departamento de Zoologia, Laboratório de Herpetologia, Instituto de Biociências, Universidade Federal do Rio Grande do Sul, Avenida Bento Gonçalves, 9500, bloco IV, prédio 43435, 91501-970 Porto Alegre, RS, Brazil. (carolzank@ hotmail.com; pulchella@gmail.com) 2. In memoriam.

3. Sección Zoología Vertebrados, Facultad de Ciencias, Universidad de la República, Iguá 4225, 11400 Montevideo, Uruguay. (rmaneyro@adinet.com.uy)

4. Laboratório de Herpetologia, Faculdade de Biociências e Museu de Ciências e Tecnologia, Pontifícia Universidade Católica do Rio Grande do Sul. Av. Ipiranga 6681, 90619-900 Porto Alegre, RS, Brazil. (cinolebia@ hotmail.com)

5. Laboratório de Vertebrados, Departamento de Ecologia, Universidade do Estado do Rio de Janeiro. Av. São Francisco Xavier 524, PHLC, sala 224, Maracanã, 20550-013 Rio de Janeiro, RJ, Brasil. (lufusinatto@gmail.com)

\begin{abstract}
We studied the reproductive biology of a population of Pseudis minuta Günther, 1858 from Reserva Biológica do Lami (30 $15^{\prime} \mathrm{S} ; 51^{\circ} 05^{\prime} \mathrm{W}$ ), Porto Alegre, southern Brazil. We assessed the spatial and temporal distribution of individuals (males, females, juveniles) and explored potential relationships with environmental variables. Field activities encompassed bimonthly surveys in three semi-permanent ponds, each one during approximately two days and two nights, from August 2004 to July 2005. We recorded differences in the sites used by males, females and juveniles, with males occupying deeper and more distant places from the border. The temporal distributions of individuals, calling sites and amplectant pairs indicated that the reproductive activity of $P$. minuta is related to some of the studied abiotic factors. Calling males presented statistical differences in relation to non-calling males for all daily abiotic variables analyzed (air temperature, water temperature, relative humidity and rainfall), as well as to monthly temperature and rainfall. The number of active males, females and juveniles was influenced by at least one of the daily or monthly environmental variables analyzed. We conclude that the reproduction in this species is seasonal and may be partially determined by abiotic factors.
\end{abstract}

KEYWORDS. Spatial-temporal distribution, reproductive activity, environmental variables, Pseudis minuta.

RESUMO. Distribuição espacial e temporal de Pseudis minuta (Anura, Hylidae, Hylinae) e variáveis ambientais relacionadas à atividade reprodutiva na Reserva Biológica do Lami, sul do Brasil. A distribuição espacial e temporal de Pseudis minuta Günther, 1858 e fatores ambientais relacionados à atividade reprodutiva da espécie foram estudados na Reserva Biológica do Lami $\left(30^{\circ}\right.$ $\left.1^{\prime} \mathrm{S} ; 51^{\circ} 05^{\prime} \mathrm{W}\right)$, Porto Alegre, Brasil. As atividades de campo compreenderam visitas bimensais a três banhados semi-permanentes, com duração aproximada de dois dias e duas noites cada, entre agosto de 2004 e julho de 2005. Observaram-se diferenças nos sítios utilizados por machos, fêmeas e juvenis, com machos ocupando locais mais profundos e mais distantes da margem. A distribuição temporal dos indivíduos, vocalizações e amplexos indicaram que a atividade reprodutiva de $P$. minuta está relacionada com alguns dos fatores abióticos estudados. Os machos em atividade de vocalização apresentaram diferença significativa em relação aos machos não vocalizantes para todos os fatores abióticos diários analisados (temperatura do ar, temperatura da água, umidade relativa do ar e pluviosidade), bem como na temperatura do ar e pluviosidade mensais. O número de machos, fêmeas e juvenis em atividade foi influenciada por pelo menos um dos fatores ambientais mensais ou diários analisados. Conclui-se que a reprodução desta espécie é sazonal e parcialmente determinada por fatores abióticos.

PALAVRAS-CHAVE. Distribuição espaço-temporal, atividade reprodutiva, variáveis ambientais, Pseudis minuta.

The climate plays an important role on the activity pattern and reproduction of amphibians. In temperate regions the main abiotic factor that influences the reproductive activity of anuran amphibians is temperature, which is opposite to what happens in tropical and subtropical regions, where rainfall is the main factor (Duellman \& Trueb, 1994).

The influence of environmental factors such as rainfall, temperature and relative humidity on the reproduction of anurans was reported for several populations (e.g. Aichinger, 1987; 1992; Moreira \& Barreto, 1997; Bernarde \& Machado, 2001; Marsh, 2000; Oseen \& Wassersug, 2002; Vaira, 2005). Additionally, there are intrinsic factors (i.e. internal rhythms, ontogenic changes) influencing the activity patterns of amphibians (WELLS, 1977; MorRISON \& HERO,
2003). So, reproductive activity is expected to be related to a combination of both, extrinsic and intrinsic factors (CAMARGO et al., 2005). However, similar environmental conditions may produce different responses depending on the species and, mainly, its reproductive strategies.

The spatial and temporal distribution of anuran species varies according to the reproductive pattern (explosive or prolonged reproduction), the reproductive strategy, and the reproductive mode of each species. During the reproductive period, males of many species form aggregations aiming to attract females and breed (Wells, 1977; LaVilla \& Rougés, 1992; Bastos \& HADDAD, 1996), but these aggregations follow patterns that are known for only few species (AICHINGER, 1987; GERHARDT et al., 1989; MitCHELl, 1991; BASTOS \& HADDAD, 1999).

This study aimed to describe aspects related to the 
spatial and temporal distribution of the individuals of a Pseudis minuta Günther, 1858 population from eastern Depressão Central (Central Depression) of the state of Rio Grande do Sul, and to associate the influence of environmental factors to their presence and calling activity.

\section{MATERIAL AND METHODS}

Field activities were carried out in semi-permanent ponds in Reserva Biológica do Lami $\left(30^{\circ} 15^{\prime} \mathrm{S} ; 5^{\circ} 05^{\prime} \mathrm{W}\right)$, a protected area with approximately 179 ha, located in the southern end of Porto Alegre municipality, Rio Grande do Sul, Brazil. This protected area shows a moderate mesothermic climate of a temperate type, without a dry season and with an annual mean temperature varying from $18-20^{\circ} \mathrm{C}$ (NIMER, 1990). Local vegetation is inserted in the ecotone between Deciduous Seasonal Forest and Dense Ombrophilous Forest (Atlantic Forest), characterized by the presence of wetlands, restinga forests and grasslands (BRACK et al., 1998). Three semipermanent ponds were selected for this study with areas of approximately 205, 818, and 4,097 $\mathrm{m}^{2}$.

During the sampling period, from August 2004 to July 2005, the study area was visited twice a month. The ponds were waded in search of individuals, which were manually caught. Data recorded for each individual were distance and sex of the nearest individual of the same species, distance to border and water depth. Individuals were sexed, weighted to the nearest $0.1 \mathrm{~g}$ with a Pesola spring scale and measured (snout-vent length - SVL) with a digital caliper to the nearest $0.1 \mathrm{~mm}$. Before being released, each specimen was marked using the freezebranding technique (DAUGHERTY, 1976), which means individual ventral marks made by contact with liquid nitrogen. Right after those procedures, each individual was released at its capture site.

Individuals were considered mature as follows: males with SVL from $20.6 \mathrm{~mm}$ and mass from $1.3 \mathrm{~g}$; females with SVL from $32.0 \mathrm{~mm}$ and mass from $4.4 \mathrm{~g}$ (MELCHIORS et al., 2004).

Water and air temperatures were recorded in the beginning and at the end of each sampling. These records were complemented with information obtained through the $8^{\text {th }}$ Meteorological District of Porto Alegre $(30 \mathrm{~km}$ from the study area) about total daily and monthly rainfall and mean daily and monthly relative humidity and temperature.

The sexual ratio for the population was tested using $\chi^{2}$ test by month. Differences in spatial distribution (border distance, water depth) among males, females and juveniles were tested by Kruskall-Wallis test and an $a$ posteriori Mann-Whitney U test). Correlations between calling frequencies and abiotic factors were tested by Mann-Whitney U test, at two scales: daily and monthly.
Finally, correlations between environmental factors and abundance in each group (males, females and juveniles) were tested by the Kendall tau rank correlation coefficient. Data analysis was carried out using Statistica 5.5 for Windows (StaTSoft, 1999).

\section{RESULTS}

General population pattern. Activity of individuals varied according to sex, age and month (Tab. I). Males were active during all months, except for January to March, when the ponds were dried out. There was an increase in the number of active males from April to September and a decrease in the following months. Calls were recorded from May to November, with a peak in September. Females were active from April to December; juveniles were recorded from October to April. Amplexi were observed from August to October.

The sexual ratio of the population was significantly different from 1:1 in July $\left(\chi^{2}=10.80 ; \mathrm{p}<0.005 ; \mathrm{n}=36 ; \mathrm{n}_{0}\right.$ $=13)$, August $\left(\chi^{2}=13.36 ; \mathrm{p}<0.001 ; \mathrm{n}^{2}=27 ; \mathrm{n}_{\mathrm{O}}=6\right)$, September $\left(\chi^{2}=62.23 ; \mathrm{p}<0.001 ; \mathrm{n}_{O^{7}}=81 ; \mathrm{n}_{\odot}=7\right)$ and October $\left(\chi^{2}=22.53 ; \mathrm{p}<0.05 ; \mathrm{n}_{0^{2}}=28 ; \mathrm{n}_{0}=2\right)$. Seasonal analysis recorded differences in Autumn $\left(\chi^{2}=5.06 ; \mathrm{p}<\right.$ $\left.0.05 ; \mathrm{n}_{0^{7}}=41 ; \mathrm{n}_{\odot}=23\right)$, Winter $\left(\chi^{2}=81.91 ; \mathrm{p}<0.001 ; \mathrm{n}_{\bigcirc^{7}}=\right.$ $\left.144 ; \mathrm{n}_{\odot}=26\right)$ and Spring $\left(\chi^{2}=27.52 ; \mathrm{p}<0.001 ; \mathrm{n}_{\bigcirc^{7}}=38 ; \mathrm{n}_{\odot}=\right.$ 4). Summer months (December to March) were not analyzed due to the drought that took place during this period.

Spatial and temporal distribution. Significant differences among age-sex classes were found for the environmental variables border distance $(\mathrm{KW}=7.505$, $\mathrm{p}$ $=0.024)$ and water depth $(\mathrm{KW}=7.734, \mathrm{p}=0.021)$. Performing an a posteriori test, there was significant difference between border distance $(\mathrm{U}=3084.5 ; \mathrm{p}<0.05)$ kept by males $(n=157)$ and females $(n=52)$ and water depth $(\mathrm{U}=1956.5 ; \mathrm{p}<0.05)$ used by males $(\mathrm{n}=158)$ and juveniles $(n=35)$ (Fig. 1). So, males used sites farther from the border than females and deeper than juveniles. The distance to the nearest individual was independent of sex and age of the involved individuals $(\mathrm{KW}=0.43$; $\mathrm{p}$ $>0.05)$ the smaller distance recorded $(0.05 \mathrm{~m})$ was between two calling males.

Daily and monthly environmental factors. During this study, there was an atypical drought period in Rio Grande do Sul, which lasted from December 2004 to February 2005 (Fig. 2). The ponds in the study area dried out in December and remained dry until middle May.

Comparing calling males $(n=66)$ with non-calling males $(n=92)$, there were significant differences regarding total monthly rainfall $(\mathrm{U}=1,699, \mathrm{p}<0.001)$ and mean monthly air temperature $(U=2,469 ; \mathrm{p}<0.05)$ recorded in each group (Fig. 3). There was no significant difference between the groups of calling and non-calling males

Table I. Temporal distribution of males, females, juveniles, calling individuals and amplexus of Pseudis minuta Günther, 1858 in Reserva Biológica do Lami, southern Brazil from August 2004 to July 2005.

\begin{tabular}{|c|c|c|c|c|c|c|c|c|c|c|c|c|}
\hline & AUG & SEPT & OCT & NOV & DEC & JAN & FEB & MAR & APR & MAY & JUNE & JULY \\
\hline Males & 27 & 81 & 28 & 4 & 6 & 0 & 0 & 0 & 4 & 18 & 19 & 36 \\
\hline Females & 6 & 7 & 2 & 1 & 1 & 0 & 0 & 0 & 2 & 10 & 11 & 13 \\
\hline Juveniles & 0 & 0 & 4 & 15 & 13 & 1 & 0 & 0 & 3 & 0 & 0 & 0 \\
\hline Callings & 1 & 35 & 11 & 1 & 0 & 0 & 0 & 0 & 0 & 3 & 2 & 13 \\
\hline Amplexus & 1 & 2 & 1 & 1 & 0 & 0 & 0 & 0 & 0 & 0 & 0 & 0 \\
\hline
\end{tabular}


concerning mean monthly relative humidity $(\mathrm{U}=2,677.5$; $\mathrm{p}=0.2$; non-calling $=92 ;$ calling $=66$ ) .

At daily scale, there were significant differences of air temperature $(\mathrm{U}=1,458.5 ; \mathrm{p}<0.001)$, water temperature $(\mathrm{U}=1,502 ; \mathrm{p}<0.001)$, relative humidity $(\mathrm{U}=2,331 ; \mathrm{p}<0.05)$ and rainfall $(\mathrm{U}=1,599 ; \mathrm{p}<0.001)$ concerning the presence of calling $(n=66)$ and non-calling males $(n=92)$ (Fig. 4).

The number of males was significantly correlated to the daily air temperature; the number of females was significantly correlated with the daily air temperature, water temperature and relative humidity; the number of juveniles was significantly correlated with the daily water temperature and relative humidity (Tab. II).
At monthly scale, the number of males, females and juveniles was significantly correlated with mean air temperature and mean relative humidity; the number of males had a marginal correlation to total rainfall (Tab. III).

Displacements, mark and recapture. During the sampling period 145 individuals of Pseudis minuta were marked, being 97 males, 33 females and 15 juveniles. Approximately $23 \%$ (21 males, 10 females and 2 juveniles) of them were recaptured; five were recaptured more than once. Based on marks and recaptures, three displacements between the swamps were recorded. One individual was marked when it was juvenile and recaptured after seven months, identified as adult male,
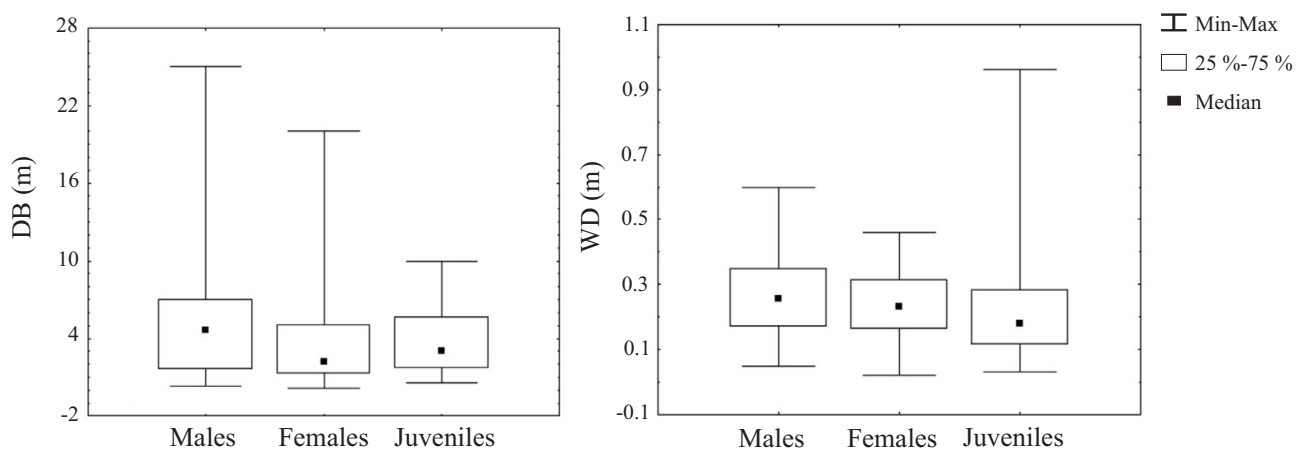

Figure 1. Distance from the border $(\mathrm{DB}, \mathrm{m})$ and water depth $(\mathrm{WD}, \mathrm{m})$ recorded in males, females and juveniles of Pseudis minuta Günther, 1858 in Reserva Biológica do Lami, southern Brazil from August 2004 to July 2005.

Table II. Results of the Kendall test for the relationship between number of Pseudis minuta Günther, 1858 recorded individuals and the daily environmental variables in Reserva Biológica do Lami, southern Brazil from August 2004 to July 2005. Significant differences ( $p<0.05)$ are indicated by an asterisk (AT, air temperature; F, females; J, juveniles; M, males; R, rainfall; RH, relative humidity; WT, water temperature).

\begin{tabular}{llccc}
\hline & $\mathrm{N}$ & Tau & $\mathrm{Z}$ & $\mathrm{p}$ \\
\hline M \& AT & 23 & $-0.411891^{*}$ & $-2.752189^{*}$ & $0.005920^{*}$ \\
M \& WT & 18 & -0.250023 & -1.448954 & 0.147350 \\
M \& RH & 23 & 0.239290 & 1.598897 & 0.109844 \\
M \& R & 23 & 0.015376 & 0.102737 & 0.918172 \\
F \& AT & 23 & $-0.370999^{*}$ & $-2.478958^{*}$ & $0.013177^{*}$ \\
F \& WT & 18 & $-0.353536^{*}$ & $-2.048841^{*}$ & $0.040478^{*}$ \\
F \& RH & 23 & $0.373649 *$ & $2.496665^{*}$ & $0.012537^{*}$ \\
F \& R & 23 & 0.169285 & 1.131138 & 0.257997 \\
J \& AT & 23 & 0.101983 & 0.681437 & 0.495595 \\
J \& WT & 18 & $0.464064 *$ & $2.689384^{*}$ & $0.007158^{*}$ \\
J \& RH & 23 & $-0.341299 *$ & $-2.280505 *$ & $0.022578^{*}$ \\
J \& R & 23 & -0.054707 & -0.365546 & 0.714704 \\
\hline
\end{tabular}

Table III. Results of the Kendall test for the relationship between number of Pseudis minuta Günther, 1858 individuals and the monthly environment variables in Reserva Biológica do Lami, southern Brazil from August 2004 to July 2005. Significant differences ( $<0.05$ ) are indicated by an asterisk (AT, air temperature; F, females; J, juveniles; M, males; R, rainfall; RH, relative humidity).

\begin{tabular}{llccc}
\hline & $\mathrm{N}$ & $\mathrm{Tau}$ & $\mathrm{Z}$ & $\mathrm{p}$ \\
\hline M \& AT & 23 & $-0.530556^{*}$ & $-3.545091^{*}$ & $0.000392^{*}$ \\
M \& RH & 23 & $0.298508^{*}$ & $1.994585^{*}$ & $0.046088^{*}$ \\
M \& R & 23 & $0.286332^{*}$ & $1.913224^{*}$ & $0.055719^{*}$ \\
F \& AT & 23 & $-0.614653^{*}$ & $-4.107014^{*}$ & $0.000040^{*}$ \\
F \& RH & 23 & $0.504348^{*}$ & $3.369972^{*}$ & $0.000752^{*}$ \\
F \& R & 23 & 0.192920 & 1.289063 & 0.197376 \\
J \& AT & 23 & $0.387665^{*}$ & $2.590317^{*}$ & $0.009589^{*}$ \\
J \& RH & 23 & $-0.341394^{*}$ & $-2.281144^{*}$ & $0.022540^{*}$ \\
J \& R & 23 & -0.129222 & -0.863439 & 0.387896 \\
\hline
\end{tabular}


at about $123 \mathrm{~m}$ from its original swamp. One female and one juvenile were recaptured 18 days and 14 days after their marking, respectively; the female had moved about $81 \mathrm{~m}$ and the juvenile $123 \mathrm{~m}$.

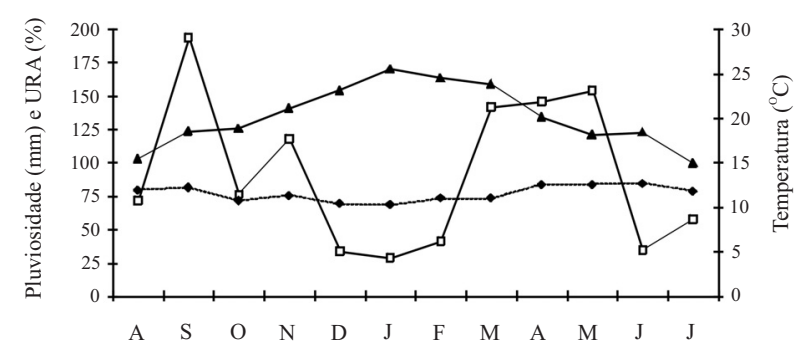

Figure 2. Total monthly rainfall (square, mm), mean monthly relative humidity (lozenge, \%) and mean monthly air temperature (triangle, ${ }^{\circ} \mathrm{C}$ ) from August 2004 to July 2005 in Porto Alegre, southern Brazil (data from the $8^{\text {th }}$ Meteorological District of Porto Alegre).

\section{DISCUSSION}

The spatial and temporal distribution of anurans is fairly studied, either concerning calling sites of adult males or concerning use of microenvironments by tadpoles (e.g. CARDoso et al., 1989; ANDRADE \& CARDOSO, 1991; Pombal, 1997; Bertoluci \& Rodrigues, 2002; Toledo et al., 2003; Melchiors et al., 2004). However, few studies assess spatial and temporal distribution of females and juveniles and study synchrony and chronology of events that happen in periods other than the reproductive season (see CAMARGO et al., 2005). Nothing was known concerning to those subjects for $P$. minuta, or for any other species belonging to this genus.

Males of P. minuta used sites farther from border and deeper than those used by females and juveniles, respectively. This characteristic on the use of the space may be a consequence of males requirements for sites for calling and amplexus. These kind of sites are available
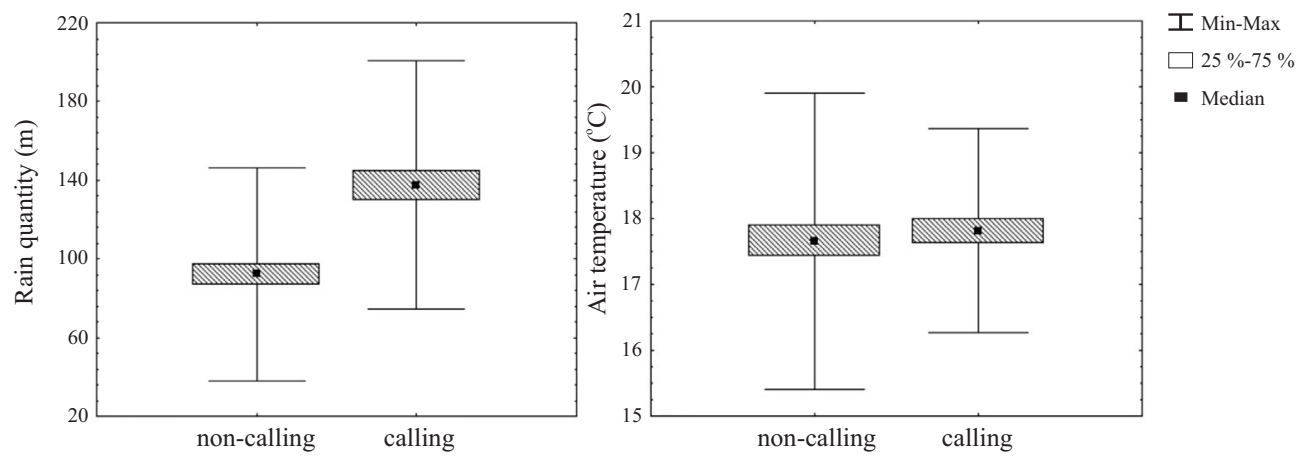

Figure 3. Frequencies of total monthly rainfall (in mm) and mean monthly air temperature (in ${ }^{\circ} \mathrm{C}$ ) in Reserva Biológica do Lami, southern Brazil related to the presence of calling and non-calling males of Pseudis minuta Günther, 1858 from August 2004 to July 2005.
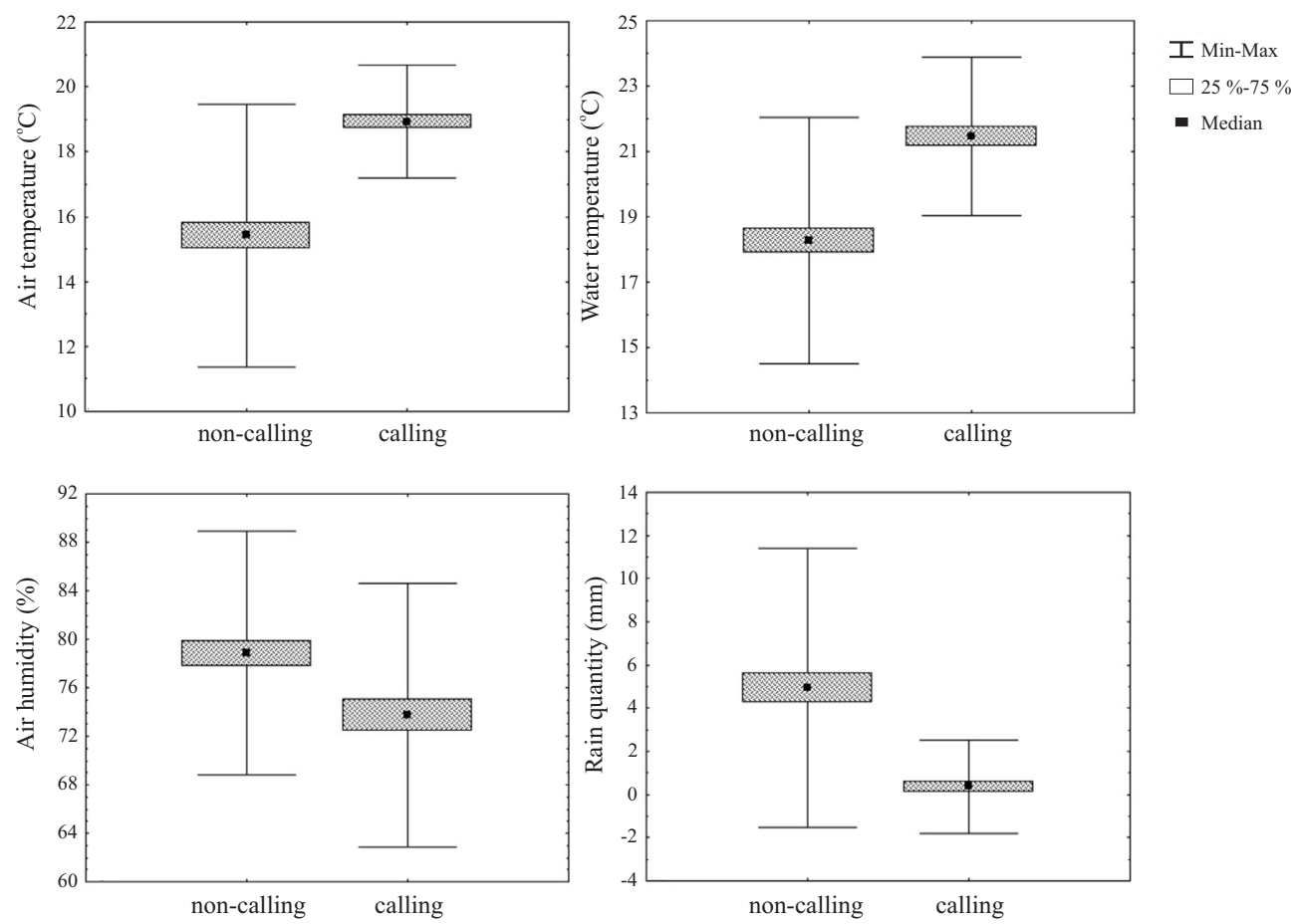

Figure 4. Frequencies of four daily environment variables in Reserva Biológica do Lami, southern Brazil related to the presence of calling and non-calling males of Pseudis minuta Günther, 1858 from August 2004 to July 2005. 
in larger number in regions nearer the middle of the ponds, hence, in the deeper portions. Around $35 \%$ of the males were found calling on aquatic plants which were only available in regions far from the border (ZANK et al., 2008).

Some authors commented the importance of the space between calling males (GERHARDT et al., 1989; Mitchell, 1991). The distance between individuals varied independently from sex or calling activity in this study. Maintenance of a minimum space is likely advantageous only in locations where there is large density of males because it helps to decrease the number of aggressive interactions, as observed in a population of Pseudis boldodactyla A. Lutz, 1925 (VAz-SILVA et al., 2007).

Records of greater number of individuals, callings and mainly of amplexi from August to November indicate that the species has prolonged seasonal reproductive activity in the study area, as observed in other regions (LAVILla \& Rougés, 1992; Langone, 1995; Melchiors et al., 2004). Taking into consideration that spermatozoa and mature ovums are present all over the year (LAVILLA \& RougÉs, 1992; MelCHIORS et al., 2004), the reproduction of the species seems to be actually conditioned by extrinsic factors, like formerly suggested by MELCHIORS et al. (2004). The strong influence of the temperature, relative humidity and rainfall, either on the presence of individuals or on the calling activity of males, reinforces this evidence.

The sex ratio was significantly different from 1:1 from July to October and in all sampled months the number of observed males was higher than the number of observed females. The period between July and October corresponded to that in which the individuals were active for reproduction, that is, when males were more conspicuous than females due to callings. Amplectant pairs were observed between August and November, so the increase on visibility of males may be related to reproductive events (since amplexus is an unmistakable signal of reproduction). This could be interpreted as males beginning to prepare (perhaps territoriality) for reproduction, so we observed amplexi immediately after the increase of males calling activities. This follows the same vein as the correlations observed with abiotic factors. Additionally, the major abundance of males compared to the number of females is expected for nonexplosive breeding frogs (WELLS, 1977).

Abiotic factors such as relative humidity, rainfall and temperature influence reproductive activity of anurans (e.g. Aichinger, 1987, 1992; DONNELY \& GUYER, 1994; Pombal et al., 1994; BerToluCI, 1998). However, the response to a rainy night may vary depending on the seasonal or annual rainfall (MARSH, 2000).

Pseudis minuta presents the most generalized and phylogenetically primitive reproductive mode among anurans (BASsO, 1990); its eggs and tadpoles develope in lentic environments. In spite of depending on aquatic environments for reproduction, the presence of individuals of $P$. minuta seems to depend more on the air temperature and relative humidity than on the monthly rainfall. In fact, species with aquatic reproduction seem to be less dependent on rains than the species with terrestrial reproductive mode (PomBAL, 1997). Moreover, in temperate regions the temperature is the main abiotic factor that determines the reproductive activity of anuran amphibians (Duellman \& Trueb, 1994).

Females seem to be more sensitive than males and juveniles to abiotic factors at daily scale, given that their presence was correlated to all factors analyzed, except for rainfall. The arrival of females to the reproductive sites probably happens mainly as a response to a combination of causes that could include abiotic factors at both daily and monthly scales (such as temperature, relative humidity) and male calling activity.

As was observed in $P$. minuta, the calling activity of other anuran species presents correlation to abiotic factors such as air temperature and monthly rainfall (e.g. Andrade \& CARdoso, 1991; Moreira \& BARRETO, 1997; Bernarde \& Machado, 2001; Oseen \& Wassersug, 2002; GotTSBERGER \& GRUBER, 2004). The correlation between daily abiotic factors and calling activity may be explained by the great energetic waste of males on this activity (Duellman \& Trueb, 1994; Smith et al., 2003). It would be disadvantageous for a male, to spend a great amount of energy calling in days when the abiotic factors do not favor reproduction. Additionally, calling activities may have other relevant functions at species level, like territorial defense, which is related to sexual selection processes (Duellman \& Trueb, 1994).

Anurans normally migrate in the beginning of the reproductive period from the areas where they spend the less favored season to more favored locations for reproduction (LAVILLA \& RougÉs, 1992). Recently, Miranda et al. (2005) recorded displacements of individuals of Pseudis cardosoi Kwet, 2000 between ponds in a population from northeastern Rio Grande do Sul. The greatest displacement in that study was $83.5 \mathrm{~m}$. Two displacements of approximately $120 \mathrm{~m}$ were recorded in this study between the swamps sampled. Thus, displacements on earth surface of individuals of the species of this exclusively aquatic genus seem to be longer and more common than it was known so far. However, the function of these displacements remains unknown, and feeding activities (i.e. active search for prey) or looking for refugia could not be discarded.

Acknowledgments. We are thankful to Volkmer, G.; Zank, I. M. O.; Zank, S.; Santos-Jr., A. P.; Guedes, A.; Schussller, G.; Miorando, P. S.; Hassdenteufel, C. B.; Vaz-Silva, W.; Frota, J. G.; Balestrin, R. L.; Cappellari, L. H.; D’Agostini, F. M. and Cognato, D. for helping in fieldwork and Ribeiro, S. L. B.; Aguiar, F. S.; Lema, T.; Silva, C. N.; Albuquerque, N. R.; Melchiors, J.; Outeiral, A. B.; Bonfiglio, F.; Pontes, G. M. F. and Oliveira, R. B. for help during laboratory work and valuable suggestions. We are thankful to Rodrigo Lingnau for making his bibliographies available to us. To CAPES and CNPq (process 307.992/2004-7) for the grant to Zank, C. and Di-Bernardo, M., respectively. Maneyro, R. has a doctoral fellowship from Coordenação de Aperfeiçoamento de Pessoal de Nível Superior (CAPES). To IBAMA, for the license for collecting fauna number: 149 / 04-RAN, process number: 02010.002613 / 2004-20 and to SMAM for the research license number: $08 / 04$, process 1.055151.04.3.

\section{REFERENCES}

Aichinger, M. 1987. Annual activity patterns of anurans in a seasonal neotropical environment. Oecologia 71:583-592. 1992. Fecundity and breeding sites of an anuran community in a seasonal tropical environment. Studies of Neotropical Fauna Environment 27(1):9-18. 
Andrade, G. V. \& Cardoso, A. J. 1991. Descrição de larvas e biologia de quatro espécies de Hyla (Amphibia, Anura). Revista Brasileira de Biologia 51(2):391-402.

BAsso, N. G. 1990. Estrategias adaptativas en una comunidad subtropical de anuros. Cuadernos de Herpetología, Serie Monografías, 1:3-70.

Bastos, R. P. \& Haddad, C. F. B. 1996. Breeding activity of the Neotropical treefrog Hyla elegans (Anura, Hylidae). Journal of Herpetology 30(3):355-360.

1999. Atividade reprodutiva de Scinax rizibilis (Bokermann) (Anura, Hylidae) na Floresta Atlântica, sudeste do Brasil. Revista Brasileira de Zoologia 16(2):409-421.

Bernarde, P. S. \& Machado, A. M. 2001. Riqueza de espécies, ambientes de reprodução e temporada de vocalização da anurofauna em Três Barras do Paraná, Brasil (Amphibia:Anura). Cuadernos de Herpetología, Serie Monografías, 14:93-104.

Bertoluci, J. 1998. Annual patterns of breeding activity in Atlantic Rainforest anurans. Journal of Herpetology 32(4):607611.

Bertoluci, J. \& Rodrigues, M. L. 2002. Utilização de habitats reprodutivos e micro-habitats de vocalização em uma taxocenose de anuros (Amphibia) da Mata Atlântica do sudeste do Brasil. Papéis Avulsos de Zoologia 42(11):287-297.

Brack, P.; Rodrigues, R. S.; Sobral, M. \& Leite, S. L. C. 1998. Árvores e arbustos da vegetação natural de Porto Alegre, Rio Grande do Sul, Brasil. Iheringia, Série Botânica, 51(2):139166.

Camargo, A.; Naya, D. E.; Canavero, A.; Da Rosa, I. \& Maneyro, R. 2005. Seasonal activity and the body size - fecundity relationship in a population of Physalaemus gracilis (Boulenger, 1883) (Anura, Leptodactylidae) from Uruguay. Annales Zoologici Fennici 42(5):513-521.

Cardoso, A. J.; Andrade, G. V. \& Haddad, C. F. B. 1989. Distribuição espacial em comunidades de anfíbios (Anura) no sudeste do Brasil. Revista Brasileira de Biologia 49(1):241-249.

DAugherty, C. H. 1976. Freeze-branding as a technique for marking anurans. Copeia 1976:836-838

Donnelly, M. A. \& GuYer, C. 1994. Patterns of reproduction and habitat use in an assemblage of Neotropical hylid frogs. Oecologia 98:291-302.

Duellman, W. E. \& Trueb, L. 1994. Biology of amphibians. Maryland, Johns Hopkins University. 670p.

Gerhardt, H. C.; Diekamp, B. \& Ptacek, M. 1989. Inter-male spacing in choruses of the spring peeper, Pseudacris (Hyla) crucifer. Animal Behaviour 38(6):1012-1023.

Gottsberger, B. \& Gruber, E. 2004. Temporal partitioning of reproductive activity in a Neotropical anuran community. Journal of Tropical Ecology 20:271-280.

LANGONE, J. A. 1995. Ranas y sapos del Uruguay (Reconocimiento y aspectos biológicos). Museo Damaso Antonio Larrañaga, Serie Divulgación, 5:1-123.

Lavilla, E. O. \& Rougés, M. 1992. Reproducción y desarrollo de anuros Argentinos. Asociación Herpetológica Argentina, Serie Divulgación, 5:1-66.
Marsh, D. M. 2000. Variable responses to rainfall by breeding tungara frogs. Copeia 2000:1104-1108.

Melchiors, J.; Di-Bernardo, M.; Pontes, G. M. F.; Oliveira, R. B.; Solé, M. \& Kwet, A. 2004. Reprodução de Pseudis minuta (Anura, Hylidae) no sul do Brasil. Phyllomedusa 3(1):61-68.

Miranda, T.; Ebner, M.; Solé, M. \& Kwet, A. 2005. Estimativa populacional de Pseudis cardosoi (Anura, Hylidae), com emprego de método fotográfico para reconhecimento individual. Biociências 13(1):49-54.

Mitchell, S. L. 1991. Intermale spacing and calling site characteristics in a southern Mississippi chorus of Hyla cinerea. Copeia 1991:521-524.

Moreira, G. \& Barreto, L. 1997. Seasonal variation in nocturnal calling activity of a savanna anuran community in central Brazil. Amphibia-Reptilia 18(1):49-57.

Morrison, C. \& Hero, J. M. 2003. Geographic variation in life history characteristics of amphibians: a review. Journal of Animal Ecology 72(2):270-279.

Nimer, E. 1990. Geografia do Brasil: Região Sul. Rio de Janeiro, Fundação Instituto Brasileiro de Geografia e Estatística. v.2. 420p.

Oseen, K. L. \& WAssersug, R. J. 2002. Environmental factors influencing calling in sympatric anurans. Oecologia 133(4):616-625

Pombal JR., J. P. 1997. Distribuição espacial e temporal de anuros (Amphibia) em uma poça permanente na Serra de Paranapiacaba, sudeste do Brasil. Revista Brasileira de Biologia 57(4):583-594.

Pombal JR., J. P.; Sazima, I. \& Haddad, C. F. B. 1994. Breeding behavior of the pumpkin toadlet, Brachycephalus ephippium (Brachycephalidae). Journal of Herpetology 28:516-519.

Smith, M. J.; Withers, P. C. \& Roberts, J. D. 2003. Reproductive energetics and behavior of an Australian myobatrachid frog (Crinia georgiana). Copeia 2003:248-254.

Statsoft, Inc. 1999. Statistica for Windows (Computer program manual). Tulsa, USA. Available at: <http//www.statsoft.com>. Acesso em: 20.08.2008.

Toledo, L. F.; Zina, J. \& Haddad, C. F. B. 2003. Distribuição espacial e temporal de uma comunidade de anfíbios anuros do município de Rio Claro, São Paulo, Brasil. Holos Environment 3(2):136-149.

VAIRA, M. 2005. Annual variation of breeding patterns of the toad, Melanophryniscus rubriventris (Vellard, 1947). Amphibia-Reptilia 26(2):193-199.

Vaz-Silva, W.; Di-Bernardo, M.; Guimarães, L. D. \& Bastos, R. P. 2007. Territoriality, agonistic behavior, and vocalization in Pseudis bolbodactyla A. Lutz, 1925 (Anura:Hylidae) from Central Brazil. Salamandra 43(1):35-42.

Wells, K. D. 1977. The social behaviour of anuran amphibians. Animal Behaviour 25(3):449-455

Zank, C.; Di-Bernardo, M.; Lingnau, R.; Colombo, P.; Fusinatto, L. A. \& Fonte, L. F. M. 2008. Calling activity and agonistic behavior of Pseudis minuta Günther, 1858 (Anura, Hylidae, Hylinae) in the Reserva Biológica do Lami, Porto Alegre, Brazil. South American Journal of Herpetology 3(1):51-57. 